\title{
SOLUBLE SPD-L1 AND SERUM AMYLOID A1 AS POTENTIAL BIOMARKERS FOR LUNG CANCER
}

\author{
SOLUBILNI PD-L1 I SERUMSKI AMILOID A1 KAO \\ POTENCIJALNI BIOMARKERI ZA KARCINOM PLUĆA
}

\author{
Dragana Jovanović1,2, Marina Roksandić-Milenković1,2, Jelena Kotur-Stevuljević3, \\ Vesna Ceriman 2, Ivana Vukanić ${ }^{2}$, Natalija Samardžić2, Spasoje Popević1,2, Branislav llić2, \\ Milija Gajić ${ }^{2}$, Marioara Simon ${ }^{4}$, Ioan Simon ${ }^{5}$, Vesna Spasojević-Kalimanovska 3 , \\ Milica Belić ${ }^{3}$, Damjan Mirkov², Zorica Śumarac ${ }^{6}$, Vladislav Milenković$^{7}$ \\ ${ }^{1}$ Faculty of Medicine, University of Belgrade, Belgrade, Serbia \\ ${ }^{2}$ University Hospital of Pulmonology, Clinical Center of Serbia, Belgrade \\ ${ }^{3}$ Department for Medical Biochemistry, Faculty of Pharmacy University of Belgrade \\ ${ }^{4}$ Pulmonology Clinic "Leon Danielo«, Cluj-Napoca, Romania \\ ${ }^{5}$ Faculty of Medicine »/uliu Hatieganu«, University of Medicine and Pharmacy, Cluj-Napoca, Romania \\ ${ }^{6}$ Center for Medical Biochemistry, Clinical Center of Serbia, Belgrade \\ ${ }^{7}$ Clinic »Milenkoviću, Belgrade, Serbia
}

\section{Summary}

Background: The objective of this prospective study was to evaluate whether soluble programmed cell death1/programmed cell death-ligand 1 (PD-1/PD-L1) and serum amyloid A1 (SAA1) are potential diagnostic, predictive or prognostic biomarkers in lung cancer.

Methods: Lung cancer patients $(n=115)$ with advanced metastatic disease, 101 with non-small cell lung cancer, NSCLC (77 EGFR wild-type NSCLC patients on chemotherapy, 15 EGFR mutation positive adenocarcinoma patients, 9 patients with $\mathrm{mPD}$-L1 Expression $\geq 50 \%$ NSCLC - responders to immunotherapy), and 14 patients with small cell lung cancer (SCLC) were examined. ELISA method was used to determine sPD-L1 and SAA1 concentrations in patients' plasma.

Results: Significantly higher blood concentrations of sPD$L 1$ and SAA1 were noted in lung cancer patients compared with a healthy control group. In PD-L1 + NSCLC patients, a significantly higher SPD-L1 level was noticed compared

\section{Kratak sadržaj}

Uvod: Cilj ove prospektivne studije je bio da proceni da li su solubilna forma molekula PD-1/PD-L1 (receptor za programiranu ćelijsku smrt-1/ligand za receptor) i serumski amiloid A1 (SAA1) potencijalni dijagnostički, prediktivni ili prognostički biomarkeri kod karcinoma pluća.

Metode: Ispitivani su pacijenti sa uznapredovalim karcinomom pluća $(n=115), 101$ sa nesitnoćelijskim karcinomom pluća, NSCLC (77 pacijenata sa EGFR wild type NSCLC lečenih standardnom hemioterapijom, 15 pacijenata sa adenokarcinomom koji ima EGFR aktivacijsku mutaciju, i 9 pacijenata sa NSCLC koji ima mPD-L1 ekspresiju $\geq 50 \%$, a koji su odgovorili na imunoterapiju), i 14 pacijenata sa sitnoćelijskim karcinomom pluća (SCLC). Svim pacijentima su određene koncentracije sPD-L1 i SAA1 u plazmi ELISA metodom.

Rezultati: Značajno više koncentracije sPD-L1 i SAA1 su uočene kod pacijenata sa karcinomom pluća u poređenju sa kontrolnom grupom zdravih pojedinaca. Kod pacijenata

\footnotetext{
Address for correspondence:

Dragana Jovanović

University Hospital of Pulmonology,

Clinical Centre of Serbia

26 Koste Todorovića, Belgrade, Serbia

Phone: +38163523192

Fax: +381113348040

e-mail:draganajv@yahoo.com
} 
to any other lung cancer subgroup, as well as the highest average SAA1 value compared to other subgroups.

Conclusions: It seems that SPD-1/PD-L1 might be a potential biomarker, prognostic and/or predictive, particularly in patients treated with immunotherapy. Serum amyloid A1 has potential to act as a good predictor of patients' survival, as well as a biomarker of a more advanced disease, with possibly good capability to predict the course of disease measured at different time points.

Keywords: sPD-L1, serum amyloid A1, biomarker, PDL1 positive NSCLC

\section{Introduction}

Immune checkpoint PD-1 plays a role in controlling inflammatory response to injuries in normal lung tissues and could be critical in the pathogenesis of lung cancer. In the last decade, immune checkpoint PD-L1 expression on cancer and tumour-associated cells has become the target of checkpoint inhibitor therapy that unleashes antitumor $T$ cells and has revolutionised cancer immunotherapy (1-3).

The PD-1/PD-L1 pathway molecules including membrane-bound forms of PD-1/PD-L1 (mPD-1/ PD-L1) and recently revealed soluble forms $(4,5)$, SPD-1/PD-L1, play immunosuppressive roles in tumour-driven T-cell immune responses $(4,6)$. Soluble PD-L1 could be measured in blood by immunochemistry methods (4). Since chronic inflammation was found to be associated with tumour progression, it was assumed that many inflammatory parameters could serve as prognostic biomarkers for some tumours (7-9) including lung cancer $(10,11)$.

Serum amyloid A (SAA) is a well recognised acute inflammatory biomarker in various conditions such as infection, inflammation, malignancy (12). SAA, detected by proteomics as a potential biomarker in lung cancer, may promote metastasis in lung carcinoma cell line in vitro and has increasing blood levels at the early stage of cancer $(13,14)$. The objective of this prospective study was to evaluate whether soluble PD-1/PD-L1 and SAA1 are potential diagnostic, predictive or prognostic blood biomarkers in lung cancer.

\section{Materials and Methods}

\section{Patients}

This prospective study, approved by The Institutional Ethics Committee, included 115 eligible lung cancer patients with advanced metastatic disease, 101 of them being non-small cell lung cancer (NSCLC) patients: 77 EGFR wild-type (EGFRwt) NSCLC patients on standard chemotherapy, 15 EGFR activating mutation positive (EGFRmut) adenocarcinoma patients treated with tyrosine kinase inhibitors, and 9 patients sa PD-L1+ NSCLC uočen je značajno viši nivo sPD-L1 u poređenju sa drugim podtipovima karcinoma pluća, kao i najviša prosečna vrednost SAA1.

Zaključak: sPD-1/PD-L1 bi mogao da bude potencijalni biomarker, prognostički i/ili prediktivni, posebno kod pacijenata lečenih imunoterapijom. Serumski amiloid A1 je dobar prediktor preživljavanja, i takođe biomarker uznapredovale bolesti, sa mogućim dobrim potencijalom da predvidi tok bolesti ako se meri u različitim vremenskim tačkama.

Ključne reči: sPD-L1, serumski amiloid A1, biomarker, PD-L1 pozitivan NSCLC

with mPD-L1 Tumor Cells Expression $\geq 50 \%$ by IHH analysis, clone 22C3, DACO who were responders to immunotherapy, pembrolizumab, based on the RECIST 1.1 (Response Evaluation Criteria in Solid Tumors). The remaining 14 patients had small cell lung cancer, SCLC. We also analysed biomarkers' concentration in 30 healthy middle-aged subjects, as a control population.

\section{Sample collection}

Blood samples were collected into lithium-heparin vacutainer tubes (BD Diagnostics, Wokingham, UK). Plasma was separated by centrifugation at 1000xg RCF for 15 minutes and stored at $-80^{\circ} \mathrm{C}$, until analysis.

For the PD-L1 (B7-H1/CD274) determination in plasma, DuoSet ELISA system (R\&D Systems Europe, Ltd. Abingdon, UK) was used, as a sandwich enzyme-linked immunosorbent assay (ELISA) specific for the human B7-H1T. The lower limit was $2.0 \mathrm{ng} / \mathrm{L}$, and the upper limit was $1250 \mathrm{ng} / \mathrm{L}$. According to the manufacturer's data, reference values for healthy people in heparin-plasma samples are 33-110 ng/L.

For human serum amyloid A1 (SAA1) concentration in plasma, Duo Set ELISA system (R\&D Systems Europe, Ltd. Abingdon, UK) was used, as a sandwich enzyme-linked immunosorbent assay (ELISA) specific for the human SAA1 protein. Lower and upper limits for the SAA1 analysis were $3.13 \mathrm{ng} / \mathrm{mL}$ and 50 $\mathrm{ng} / \mathrm{mL}$, respectively.

\section{Statistical analysis}

Analyzed biomarkers' distributions deviated from normal, Gaussian distribution, and their average values were presented as medians and $25^{\text {th }}-75^{\text {th }}$ percentile values. Non-parametric methods - MannWhitney $U$ test for two groups' and Kruskal-Wallis ANOVA for three groups' comparison were used. Kaplan-Meier survival analysis was performed to test biomarkers' capability, i.e. its cut-off values (selected as an upper third value calculated for this patients' group) to predict overall patients' survival. The logrank test was selected for that analysis. Analyses were 
carried out using SPSS 18.0 (IBM, New York, USA). Statistical tests were formulated as two-sided and a $P$ value less than 0.05 All tests were 2 -sided, and a $P$ value $<0.05$ was considered statistically significant.

\section{Results}

Basic clinical data on the group of 115 lung cancer patients - subjects' age, gender, smoking status, ECOG PS score and pathohistological type are presented in Table I.

Significantly higher level of sPD-L1 in PD-L1+ patients responding to immunotherapy compared to any other lung cancer group was found. At the same time, the PD-L1+ group had the highest average SAA1 value compared to other three NSCLC groups (i.e. EGFRwt adenocarcinoma, squamous cell carcinoma and EGFRmut adenocarcinoma subgroups), as well as to SCLC (Table II).

Concentrations of sPD-L1 and SAA1 for every patient by distinct lung cancer subgroup are shown in scatter plot diagrams so that one may estimate their values compared to the upper reference limit calculated from the healthy control population.

Calculated upper reference limits for the healthy middle-aged population were also presented in the graph so that one may compare them visually with patients' values. Reference limits calculated by a nonparametric method as $2.5^{\text {th }}$ and $97.5^{\text {th }}$ percentile values for the healthy population $(\mathrm{N}=30)$ were as follows: sPD-L1: 31.0-182.5 ng/L and SAA1: 0.32$8.40 \mathrm{mg} / \mathrm{L}$. The number of patients with PD-L1 above the upper reference limit defined for healthy people $(182.5 \mathrm{ng} / \mathrm{mL})$, for different groups respectively, was: PD-L1+ (100\%), adenocarcinoma (EGFRmut, 47\%), adenocarcinoma (EGFRwt, 43\%), squamous cell carcinoma (64\%) and SCLC (31\%). SAA1 values higher than the upper reference limit of the healthy population were noted in 78\% of PD-L1+ patients, $60 \%$ of adenocarcinoma (EGFRmut), 48\% adenocarcinoma (EGFRwt), 74\% squamous cell carcinoma and $64 \%$ of SCLC patients.

The possible influence of different additional

Table I General demographic and clinical data of lung cancer patients.

\begin{tabular}{|l|c|c|c|}
\hline \multirow{2}{*}{ Characteristic } & \multirow{2}{*}{ Subgroups } & \multicolumn{2}{|c|}{ Number (\%) of patients } \\
\cline { 3 - 4 } & & $\begin{array}{c}\text { NSCLC } \\
(n=101)\end{array}$ & $\begin{array}{c}\text { SCLC } \\
(\mathrm{n}=14)\end{array}$ \\
\hline Age, years & $<60 />60$ & $22(22) / 79(78)$ & $8(57) / 6(43)$ \\
\hline Gender & Male/Female & $72(71) / 29(29)$ & $9(65) / 5(35)$ \\
\hline Smoking status & Never/Current/Ex-smoker & $9(8.9) / 61(60) / 31(31,1)$ & $1(7) / 10(71) / 3(21)$ \\
\hline ECOG PS score & 0-1/2 & $90(89) / 11(11)$ & $14(100) / 0$ \\
\hline \multirow{3}{*}{$\begin{array}{l}\text { Pathohistological } \\
\text { finding }\end{array}$} & Adenocarcinoma (EGFRwt) & $46(46)$ & 1 \\
\cline { 2 - 3 } & Adenocarcinoma (EGFRmut) & $15(15)$ & 31(31) \\
\cline { 2 - 3 } & Squamous cell carcinoma & $9(9)$ & \\
\hline
\end{tabular}

NSCLC - non small cells lung cancer, SCLC - small cells lung cancer, ECOG PS - European Cooperative Oncology Group Performance Status

Table II Blood sPD-L1 and SAA1 concentration in lung cancer subgroups.

\begin{tabular}{|c|c|c|c|c|c|}
\hline Parameter & $\begin{array}{c}\text { Adenocarcinoma } \\
\text { (EGFRwild type) } \\
(\mathrm{N}=46)\end{array}$ & $\begin{array}{l}\text { Adenocarcinoma } \\
\text { (EGFR mutation } \\
\text { positive) } \\
(\mathrm{N}=15)\end{array}$ & $\begin{array}{l}\text { Squamouscell } \\
\text { carcinoma } \\
(N=31)\end{array}$ & $\begin{array}{c}\text { PD-L1+ NSCLC } \\
(\mathrm{N}=9)\end{array}$ & $\begin{array}{c}\text { SCLC } \\
(N=14)\end{array}$ \\
\hline sPD-L1 (ng/L) & $\begin{array}{c}161.4 \\
(104.9-272.7)\end{array}$ & $\begin{array}{c}134.4 \\
(86.0-322.5)\end{array}$ & $\begin{array}{c}196.1 \\
(98.0-317.2)\end{array}$ & $\begin{array}{c}830.3^{a a a, b b b, c c c} \\
(413.0-1185.0)\end{array}$ & $\begin{array}{c}147.3^{\mathrm{dd}} \\
(84.4-371.7)\end{array}$ \\
\hline SAA1 (mg/L) & $\begin{array}{c}9.3 \\
(2.9-28.9)\end{array}$ & $\begin{array}{c}12.6 \\
(6.7-16.2)\end{array}$ & $\begin{array}{c}23.5 \\
(9.2-28.3)\end{array}$ & $\begin{array}{c}48.0^{a a, b, c} \\
(14.5-77.0)\end{array}$ & $\begin{array}{c}26.3 \\
(7.0-38.1)\end{array}$ \\
\hline sPD-L1/SAA1 ratio & $\begin{array}{c}18.5 \\
(7.0-47.5)\end{array}$ & $\begin{array}{c}14.0 \\
(6.5-37.5)\end{array}$ & $\begin{array}{c}10.0 \\
(5.5-35.0)\end{array}$ & $\begin{array}{c}18.0 \\
(15.0-221.0)\end{array}$ & $\begin{array}{c}5.5 \\
(3.0-77.5)\end{array}$ \\
\hline
\end{tabular}

$P$ - from Mann-Whitney $U$ test; ${ }^{\text {aa, aaa }} \mathrm{P}<0.01,0.001$ vs Adenocarcinoma (EGFRwt) group; ${ }^{b, b b b} \mathrm{P}<0.05,0.001$ vs Adenocarcinoma (EGFR+mutation) group; ${ }^{c c c} \mathrm{P}<0.001$ vs Squamous cell carcinoma group, ${ }^{\mathrm{dd}} \mathrm{P}<0.05,0.01$ vs PD-L1+ group 

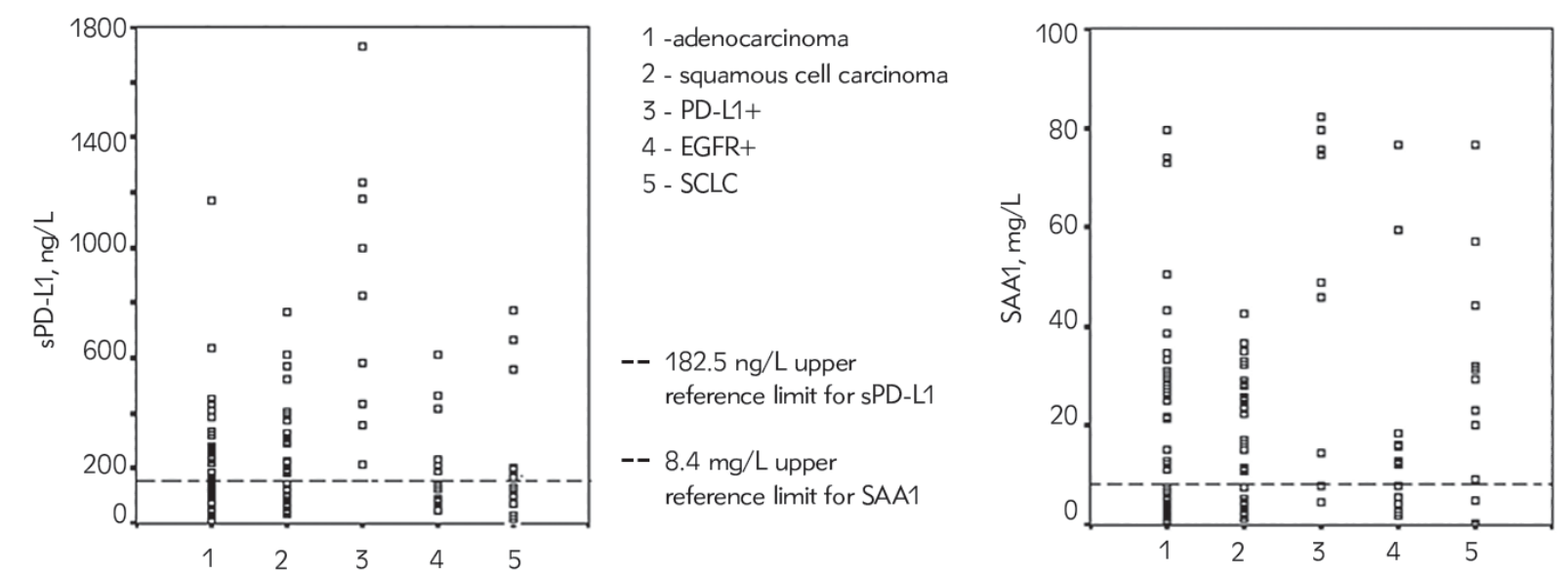

Figure 1 Scatter plot diagram of sPD-L1and SAA1 values in subgroups of lung cancer patients.

Dashed lines indicate upper reference limit for the SPD-L1 and SAA1 values from control group population.
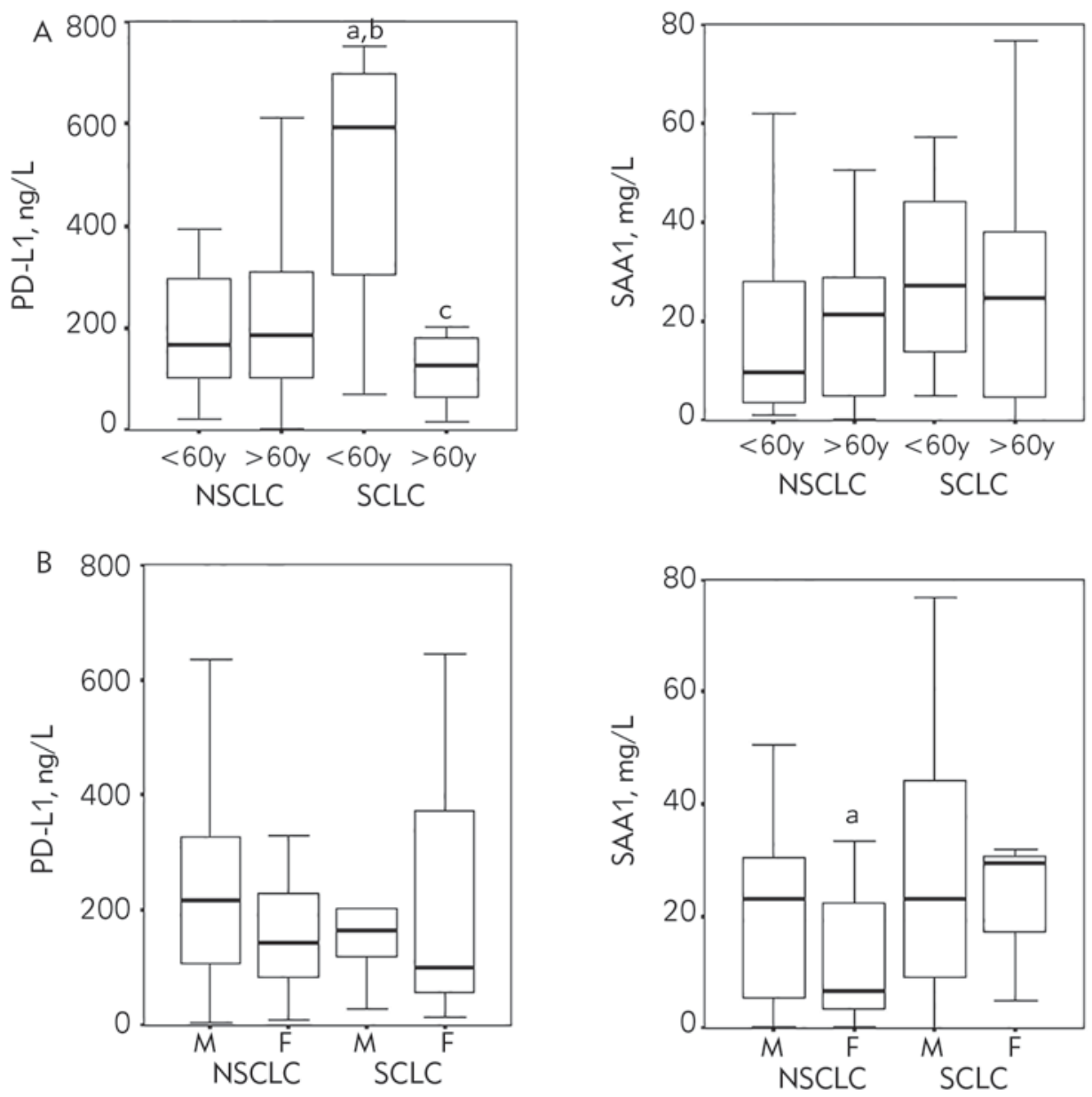

Figure 2 PD-L1 and SAA1 concentrations in NSCLC and SCLC subgroups according to

A. Age (<60 y. and >60 y.), a,b,c P<0,05 vs <60y NSCLC, >60y NSCLC, <60y SCLC, respectively, and

B. Gender (M-male, F-female), ${ }^{a}-\mathrm{P}<0.05$ vs male group in NSCLC group. 
Table III Blood sPD-L1and SAA concentrations in relation to response to chemotherapy in two lung cancer groups, NSCLC EGFRwild type and SCLC.

\begin{tabular}{|c|c|c|c|c|c|c|c|c|}
\hline \multirow[b]{2}{*}{ Parameter } & \multicolumn{4}{|c|}{ NSCLC (EGFRwt) } & \multicolumn{4}{|c|}{ SCLC } \\
\hline & $\begin{array}{c}\text { Complete } \\
\text { response } \\
(\mathrm{N}=14)\end{array}$ & $\begin{array}{l}\text { Partial response } \\
\quad(\mathrm{N}=17)\end{array}$ & $\begin{array}{c}\text { Stable disease } \\
(\mathrm{N}=23)\end{array}$ & $\begin{array}{l}\text { Disease } \\
\text { progression } \\
(\mathrm{N}=23)\end{array}$ & $\begin{array}{c}\text { Complete } \\
\text { response } \\
(\mathrm{N}=0)\end{array}$ & $\begin{array}{l}\text { Partial } \\
\text { response } \\
(\mathrm{N}=9)\end{array}$ & $\begin{array}{l}\text { Stable disease } \\
\qquad(N=2)\end{array}$ & $\begin{array}{l}\text { Disease } \\
\text { progression } \\
(\mathrm{N}=3)\end{array}$ \\
\hline $\begin{array}{l}\text { sPD-L1 } \\
\text { (ng/L) }\end{array}$ & $\begin{array}{c}199.3 \\
(111.2-323.4)\end{array}$ & $\begin{array}{c}217.0 \\
(133.6-294.2)\end{array}$ & $\begin{array}{c}207.8 \\
(98.0-383.2)\end{array}$ & $\begin{array}{c}223.0 \\
(125.4-274.8)\end{array}$ & / & $\begin{array}{c}99.3 \\
(49.3-199.8)\end{array}$ & $\begin{array}{c}436.5^{*} \\
(120.5-752.6)\end{array}$ & $\begin{array}{c}147.3 \\
(130.6-163.9)\end{array}$ \\
\hline $\begin{array}{l}\text { SAA1 } \\
(\mathrm{mg} / \mathrm{L})\end{array}$ & $\begin{array}{c}3.2 \\
(2.0-5.12)\end{array}$ & $\begin{array}{c}22.5^{* * *} \\
(9.4-31.0)\end{array}$ & $\begin{array}{c}18.9 * * \\
(3.6-29.3)\end{array}$ & $\begin{array}{c}23.1^{*} \\
(9.2-28.2)\end{array}$ & / & $\begin{array}{c}29.4 \\
(16.1-44.6)\end{array}$ & $\begin{array}{c}15.7 \\
(0.1-31.3)\end{array}$ & $\begin{array}{c}32.2 \\
(20.3-44.2)^{*}\end{array}$ \\
\hline
\end{tabular}

$\mathrm{P}<0.05,0.001$, respectively compared to complete response in NSCLC group; * $\mathrm{P}<0.05$ vs partial response sub-group in SCLC; Mann Whitney U test
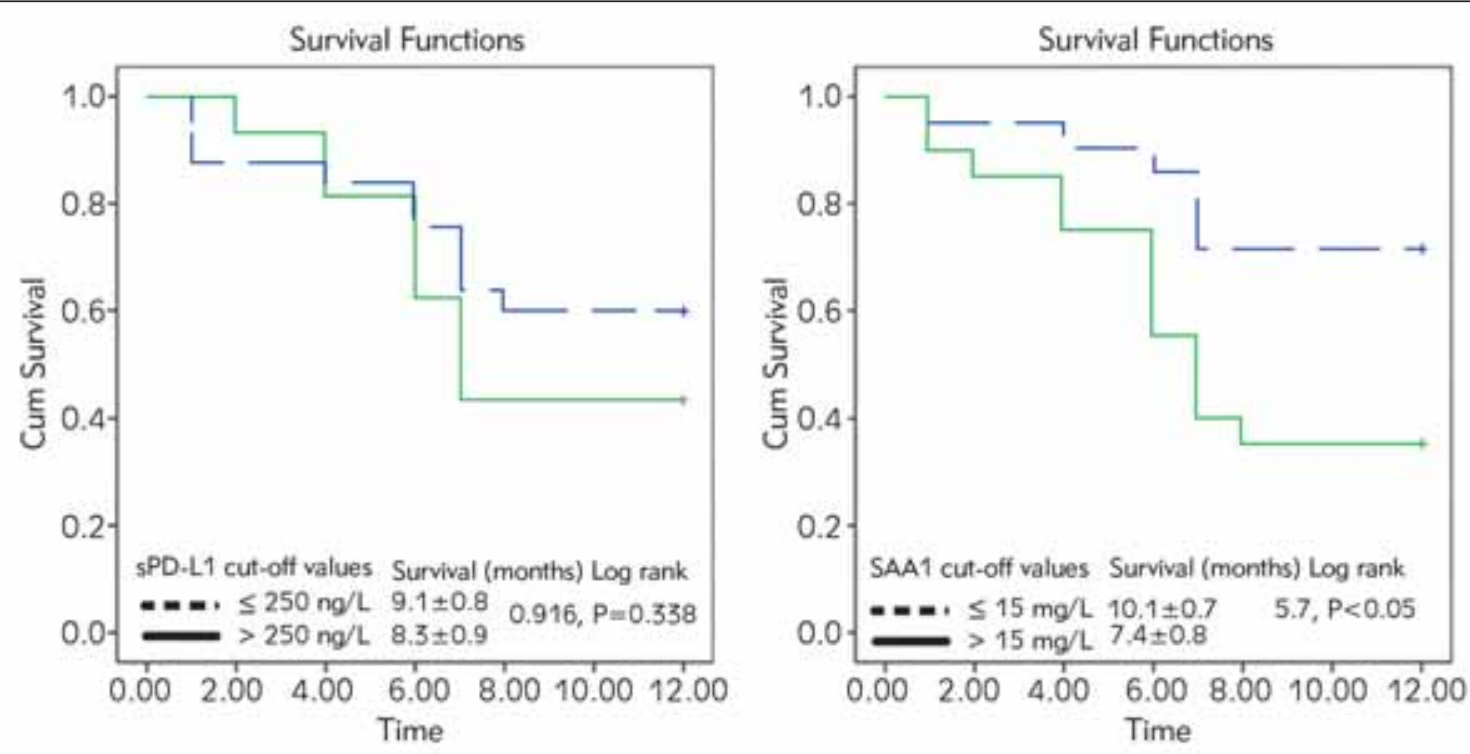

Figure 3 Kaplan-Meier analysis of overall survival in NSCLC EGFRwt patients during 12 months of study for the sPD-L1, and SAA1 values.

factors, such as gender and age on SPD-L1 and SAA1 concentrations was investigated, for the two main lung cancer groups: NSCLC and SCLC. We selected the age of as a cut-off value for age sub-groups. The highest SPD-L1 concentration was found in younger SCLC patients, compared with younger, as well as older NSCLC patients; we noticed as well significantly lower SPD-L1 in older than in younger SCLC patients (Figure 2A). SAA1 concentration was significantly higher in male subgroup compared to female, but only for NSCLC patients. Other values in gender subgroups did not differ among basic pathohystology classes (Figure 2B).

Further analysis has not shown any consistent correlation with neither the number of initially present metastases nor with the specific metastases localisation.
In the NSCLC group, patients with clinically more favourable response to chemotherapy (i.e. complete response) had significantly lower SAA1 concentration compared to less favourable responses, whereas SPD-L1 did not differ according to the therapy outcome.

In the SCLC group no patients with complete response to therapy were noted. However, sPD-L1 concentration was significantly higher $(P<0.05)$ in the stable disease group compared to partial responders (which is a clinically better status). There was no difference in SAA1 concentration among different therapy response subgroups in this pathohistological lung cancer type.

In order to test biomarkers' capability to predict overall patients' survival, we implemented KaplanMeier survival analysis in NSCLC EGFRwt patients 
throughout the 12 months of study for the sPD-L1, and SAA1 according to its cut-off values selected as upper tertile value for the whole patients' group (Figure 3).

SAA1 is a significant predictor of patients' survival according to Kaplan-Meier analysis; our current results showed that patients with SAA1 higher than $15 \mathrm{mg} / \mathrm{L}$ had shorter survival compared to patients with lower SAA1 values. Overall survival of the lung cancer patients with high SAA1 values at the study beginning was 7.4 months compared to 10.1 months in patients with lower SAA1 values.

\section{Discussion}

Tumours effectively suppress immune responses by activating negative regulatory pathways, checkpoints that are essential for immune homeostasis, or by adopting features that enable them to actively escape detection $(3,15)$. The cell-surface Programmed Death receptor 1 (membrane, mPD-1) is expressed by $T$ cells on activation in the presence of tumour cells and binds to one of two ligands, PD-L1 and PDL2. A lot of types of cells can express membrane PD$L 1$, including tumour cells and immune cells. Binding of PD-L1 or PD-L2 to PD-1 represents an inhibitory signal that prevents the activity of anti-tumour effectors $T$ cells, why the PD-L1/PD-1 axis became very important for restricting tumour immunity.

It has been revealed recently that membranebound PD-1 and PD-L1 also have soluble forms, (sPD-1/sPD-L1), detected in the blood of patients with different kinds of tumours (16).

It was supposed that SPD-L1 could be released or shed from mPD-L1-positive tumour cells or immune cells $(17,18)$. However, the accurate source of a soluble form of PD-L1 is not confirmed. The sPD-L1 is detectable in supernatants from mPD-L1 expression positive cell lines rather than in those from mPD-L1 expression negative cell lines (20). This finding indicates that mPD-L1 tumour cells might be a source of SPD-L1, but at the same time, other sources of SPD-L1 like immune cells cannot be excluded (20-23).

Many studies' objective is to elucidate the biological significance of sPD-1/PD-L1 in human cancers and to evaluate whether they are potential diagnostic, predictive, or prognostic biomarkers. Increasing evidence suggests that blood levels of sPD-1/PD-L1 might facilitate the prediction of tumour behaviour characteristics, response to treatment, and survival outcomes in cancer patients $(5,16)$.

Here, we have reported significantly higher concentrations of sPD-L1 in the serum of lung cancer patients compared with the healthy control group. The average rate of values higher than the upper reference limit in healthy people was in total $53.0 \%$ (61/115), similar to findings in other published results $(4,5,18)$ (Figure 1).

An interesting finding was the relation between the age and SPD-L1 concentration in lung cancer patients. Our findings regarding age have shown significantly higher SPD-L1 values in SCLC patients younger than 60, compared to each of NSCLC patients' subgroups. So, NSCLC and SCLC patients did not have the similar pattern of this parameter's change with ageing: NSCLC patients had no significant changes of SPD-L1 values with ageing, while contrary to published data for healthy population with increasing SPD-L1 values with ageing (19), older patients with SCLC had decreased SPD-L1 values compared to their younger counterparts (Figure 2).

The exact role and precise functions of sPD-L1 in cancer have not been determined yet. It has been proved that SPD-L1 still keeps its biological activity and is able to specifically bind to PD-1 receptor in peripheral blood, thus activating the PD-1/PD-L1 pathway with possibly consequent systemic immunosuppressive effect (16).

The exact role of sPD-L1 findings is being explored by an increasing number of studies, however with somewhat conflicting results (24-29).

Our study has shown a trend in the correlation of higher SPD-L1 blood level with more advanced disease stage (Table III), however without any consistent correlation with neither the number of initially present metastases nor with the specific metastases localisation. Regarding survival prediction, Kaplan-Meier analysis of overall survival of NSCLC patients according to the cut-off value of sPD-L1, failed to demonstrate significant survival predictive capability of sPD-L1, although patients with higher SPD-L1 values had shorter overall survival compared with subjects with lower sPD-L1 concentration (8.3 months vs 9.1 months, respectively) (Figure 3).

Some studies have reported that increased SPDL1 levels might implicate a poor prognosis or treatment resistance $(5,24)$, and that cancer patients with low SPD-L1 levels may have a longer survival time $(27,28)$, contrary to the finding that patients with higher levels of sPD-L1 had better prognosis than the low-level patients did (26).

Zhang et al. (27) reported significantly different average blood levels of SPD-L1 in patients with advanced NSCLC vs healthy controls $(P<0.001)$, while the median overall survival (OS) in the low versus high-level sPD-L1 group was significantly higher (26.8 vs 18.7 months). The expression of PDL1 in the study correlated considerably with abdominal organ metastasis. Prognostic significance of circulating soluble PD L-1 in patients with malignancies has been analysed recently in two meta-analyses as well $(17,28)$. 
Eight studies and 1,102 cancer patients were included in the final analysis of Ding et al. (28), and the findings indicated that a higher level of SPD-L1 was associated with worse overall survival. Subgroup analysis has shown significant differences in the cancer type (hematological neoplasms or non-hematological neoplasms), sample size (more or less than 100), a cut-off value of sPD-L1 (more or less than $6.51 \mathrm{ng} / \mathrm{mL}$ ) and ethnicity (Asian or European). A total of 1040 patients with solid tumours from 8 eligible studies were included in the other meta-analysis, and the pooled HR suggested that a high blood level of soluble sPD-L1 significantly correlated with worse overall survival.

As for lung cancer, it has been found that high expression of SPD-L1 was associated with the presence of epidermal growth factor receptor (EGFR) mutations in surgically resected NSCLC, this being an independent negative prognostic factor (29).

Contrary to the above, our results, although based on small series of EGFR mutation positive adenocarcinoma, had shown lower blood SPD-L1 levels in EGFR mutation positive NSCLC than in EGFRwt NSCLC, $134.4 \mathrm{ng} / \mathrm{L}$ vs $161.4 \mathrm{ng} / \mathrm{L}$ respectively. This difference was not statistically significant.

Zhao et al. (29) evaluated the sPD-L1 levels at diagnosis and during thoracic radiotherapy, in 126 inoperable, locally advanced NSCLC patients, and observed that the lower baseline SPD-L1 level significantly correlated with longer OS, shown to be an independent prognostic biomarker for this group of NSCLC patients.

In our study, although sPD-L1 did not demonstrate significant survival predictive capability, we have obtained interesting results in 9 patients with mPD-L1 expression $\geq 50 \%$. Although it was a too small number of patients, it was a striking finding in all 9 patients responders to immunotherapy of far much higher blood SPD-L1 concentrations compared to either EGFRwtNSCLC or EGFR mutation positive adenocarcinoma. It might be supposed that those results point to possible immunotherapy efficacy with consequent proteolytic cleavage of the membranebound form PD-L1 into circulation. Unfortunately, we did not have an opportunity to perform SPD-L1 determination before the onset of immunotherapy, which we intend to explore in the future. We will tailor the study in which IHH PD-L1+ tumour patients will be assigned to SPD-L1 analysis before the beginning of immunotherapy.

Regarding blood levels sPD-L1 determination, it must be emphasised that different methods with different cut-off values have been used in all these studies. Very recently, it has been demonstrated that circulating immunosuppressive tumour-derived exosomes play a key role in immune suppression and disease progression, and that elevated PD-L1 levels and PD-L1 mRNA expression on exosomes correlate with response to anti-PD-1/PD-L1 immunotherapy in melanoma and NSCLC patients providing a rationale for the application of exosomal PD-L1 as a predictor for anti-PD-1 therapy $(30,31)$.

Not only were different methods with different cut-off values used in all these studies but also important diverse ethnic populations and different patient populations as well may have influenced, at least in part, the results and the interpretation of findings.

Based on the observation that chronic inflammation was associated with tumour progression, it was postulated that many inflammatory parameters could serve as prognostic biomarkers for some tumours $(8,9)$, with lung cancer among those $(7,32)$.

Several studies have found that SAA could distinguish lung cancer patients from healthy controls and predict prognosis, thus being a potential diagnostic and prognostic biomarker for lung cancer $(33,34)$.

In our study, the SAA1 concentration was significantly higher in male subgroup compared to female, but only for NSCLC patients (Figure 2). Comparing SAA concentrations concerning patients' response to chemotherapy, no significant difference was found (Table III).

However, a significantly higher level of sPD-L1 in PD-L1+ patients responding to immunotherapy compared to any other lung cancer group was found. At the same time, the PD-L1+ group also had the highest average SAA1 values compared to the other three groups (i.e. adenocarcinoma, squamous cell carcinoma and EGFR+ groups) (Table III). It might imply that elevated SAA1 levels evidently reflect hyper-activation of the immune system in IHH mPDL1 tumour positive patients responding to immunotherapy. This clearly points to the immune-inflamed phenotype of a tumour which generally correlates with higher response rates to anti-PD-L1/PD-1 therapy (35-39). Although three basic immune phenotypes can be distinguished (immune-inflamed tumours, immune-desert, and immune-excluded tumours), there is a wide span of cytokines, chemokines and tumour-associated cell types that influence whether sufficient inflammation was present to foster a desirable anti-tumour immune response following immunotherapy. The level of inflammation can vary widely changing over time (35).

Kaplan-Meier analysis of overall survival of NSCLC patients according to cut-off values of two selected biomarkers showed that SAA1 was a better predictor of patients' survival, showing good capability to predict overall survival at the upper tertile value as a cut-off value of $15 \mathrm{mg} / \mathrm{L}$ (log-rank 5.7 , $\mathrm{P}<0.05)$. Our results showed that patients with SAA1 values below $15 \mathrm{mg} / \mathrm{L}$ lived longer, 10 months vs 7 
months averagely in patients with SAA1 above 15 $\mathrm{mg} / \mathrm{L}$ (Figure 3).

The level of SAA was found to be progressively increased with the clinical stages of lung cancer (32). Sung et al. (40) identified SAA1 and SAA2 in the pooled sera of lung cancer patients and found about 14-fold higher levels of SAA in lung cancer patients' blood samples compared to healthy controls. There is evidence that macrophages could stimulate cancer cells to produce IL-1 and IL-6, which in turn stimulate lung cancer cells to induce SAA $1 / 2$.

Serum levels of MMP-2, CRP and SAA were significantly higher in metastatic NSCLC patients than in localised NSCLC patients (12).

A systematic evaluation and meta-analysis showed that an increased SAA serum level correlated with lung cancer diagnosis $(P<0.001)$, especially with the squamous cell carcinoma ( $p=0.012$ ) (14). Squamous cell lung cancer displayed a much higher SAA level than adenocarcinoma and SCLC, pointing to the potential of using SAA for discerning squamous cell lung cancer from other types. This is contrary to our findings of similar SAA values in a squamous cell and SCLC, higher than in adenocarcinoma, but significantly lower than in IHH mPD-L1 tumour positive lung cancer (Table II).

There are several limitations to our study. The sample size is rather small, so sampling error may render a less reliable explanation of results and conclusions. Also, we did not have the opportunity to perform sPD-L1 and SAA1 determination before the onset of treatment, particularly immunotherapy, as well as $\mathrm{IHH}$ test of $\mathrm{mPD}$-L1 expression for all EGFRwt NSCLC tumours. Thus, the results have still to be explored and validated in a much larger number of lung cancer patients with different tumour types and at different time points (at the time of diagnosis, during and after different treatment modalities, during follow up), with necessary comparison of blood SPD-L1 levels not only with clinical characteristics, but also within the same group of

\section{References}

1. Brahmer JR, Tykodi SS, Chow LQ, et al. Safety and activity of anti-PD-L1 antibody in patients with advanced cancer. N Engl J Med 2012; 366(26): 2455-65.

2. Garon EB, Rizvi NA, Hui R, et al. Pembrolizumab for the treatment of non-small-cell lung cancer. $\mathrm{N}$ Engl J Med 2015; 372(21): 2018-28.

3. Topalian SL, Drake CG, Pardoll DM. Immune checkpoint blockade: a common denominator approach to cancer therapy. Cancer Cell 2015; 27: 450-61. patients with corresponding tumor biopsy mPD-L1 expression.

Furthermore, patients included in this study are Caucasians only, while the majority of discussed studies are dealing with patients of Asian ethnicity, which may influence the results with population bias. Experience from oncogene driver mutations, more studies with well-defined specific area patients should be performed in order to obtain more generalizable results. Largely varied cut-off values of sPD-L1 among published studie, which need clarification and methodology validation are another serious and obvious problem.

\section{Conclusion}

Our study revealed significantly higher concentrations of sPD-L1 and SAA1 in the serum of lung cancer patients compared with healthy control group. Significantly higher level of SPD-L1 in PD-L1+ patients and responders to immunotherapy was observed compared to any other lung cancer subgroup, and the highest average SAA1 value compared to other subgroups as well. It may be speculated that sPD-1/PD-L1 might provide new biomarkers, prognostic and/or predictive, particularly in patients treated with immunotherapy only, or in combination with other anticancer agents. This study points clearly to its potential of SAA1 to act as good predictor of patients' survival, as well as a biomarker of a more advanced disease, measured at different time points.

Acknowledgements. This work was supported by the Ministry of Education, Science and Technological Development of Serbia, Project numbers 175046, III 43007 and 175035.

\section{Conflict of interest statement}

The authors stated that they have no conflicts of interest regarding the publication of this article.
4. Zhu X, Lang J. Soluble PD-1 and PD-L1: predictive and prognostic significance in cancer. Oncotarget 2017; 8(57): 97671-82.

5. Okuma Y, Hosomi Y, Nakahara Y, et al. High plasma levels of soluble programmed cell death ligand 1 are prognostic for reduced survival in advanced lung cancer. Lung Cancer 2017;104:1-6.

6. Park HJ, Park JS, Jeong YH, et al. Correction: PD-1 Upregulated on Regulatory $T$ Cells during Chronic Virus Infection Enhances the Suppression of CD8 + T Cell Immune 
Response via the Interaction with PD-L1 Expressed on CD8+ T Cells. J Immunol 2015; 195: 5841-2.

7. Zhang $X Y$, Zhang $G$, Jiang $Y$, et al. The prognostic value of serum $C$ reactive protein bound serum amyloid $A$ in early stage lung cancer. Chin J Cancer 2015; 34: 39.

8. Mantovani A, Allavena P, Sica A, et al. Cancer-related inflammation. Nature 2008; 454(7203): 436-44.

9. Kiani A, Abedini A, Adcock MI, Mirenayat SM, Taghavi K, Mortaz E, Kazempour-Dizaji M. Association between vitamin d deficiencies in sarcoidosis with disease activity, course of disease and stages of lung involvements. J Med Biochem 2018; 37: 103-9.

10. Cho WC, Kwan CK, Yau S, et al. The role of inflammation in the pathogenesis of lung cancer. Expert Opin Ther Targets 2011; 15(9): 1127-37.

11. Warawdekar UM, Sirajuddin MM, Pramesh CS, et al. An approach of selecting appropriate markers from the primary tumour to enable detection of circulating tumour cells in patients with non-small cell lung cancer. J BUON 2015; 20(3): 782-90.

12. Kanoh Y, Abe T, Masuda N, Akahoshi T. Progression of non-small cell lung cancer: Diagnostic and prognostic utility of matrix metalloproteinase-2, C-reactive protein and serum amyloid A. Oncology Reports 2013; 29: 469-73.

13. Moshkovskii SA. Why do cancer cells produce serum amyloid A acute-phase protein? Biochemistry (Mosc). 2012; 77(4): 339-41.

14. Biaoxue R, Hua L, Wenlong G, Shuanying Y. Increased serum amyloid $A$ as a potential diagnostic marker for lung cancer: a meta-analysis based on nine studies. BMC Cancer 2016;16(1): 836

15. Collinson $P$. Laboratory medicine is faced with the evolution of medical practice. J Med Biochem 2017; 36: 211-5.

16. Nagato T, Ohkuri T, Ohara K, et al. Programmed deathligand 1 and its soluble form are highly expressed in nasal natural killer/T-cell lymphoma: a potential rationale for immunotherapy. Cancer Immunol Immunother 2017; 66: 877-90.

17. Ding Y, Sun C, Li J, et al. The Prognostic Significance of Soluble Programmed Death Ligand 1 Expression in Cancers: A Systematic Review and Meta-analysis. Scandinavian J Immunol 2017; 86: 361-7.

18. Wang C, Yu X, Wang W. A meta-analysis of efficacy and safety of antibodies targeting PD-1/PD-L1 in treatment of advanced nonsmall cell lung cancer. Medicine 2016; 95: e5539.

19. Chen $Y$, Wang $Q$, Shi B, et al. Development of a sandwich ELISA for evaluating soluble PD-L1 (CD274) in human sera of different ages as well as supernatants of PD-L1+ cell lines. Cytokine 2011; 56: 231-8.

20. He XH, Xu LH, Liu Y. Identification of a novel splice variant of human PD-L1 mRNA encoding an isoformlacking Igv-like domain. Acta Pharmacol Sin 2005; 26 : 462-8.

21. Frigola $X$, Inman BA, Krco CJ, et al. Soluble B7-H1: differences in production between dendritic cells and $\mathrm{T}$ cells. Immunol Lett 2012; 142: 78-82.
22. Frigola $X$, Inman BA, Lohse $C M$, et al. Identification of a soluble form of $\mathrm{B} 7-\mathrm{H} 1$ that retains immunosuppressive activity and is associated with aggressive renal cell carcinoma. Clin Cancer Res 2011; 17: 1915-23.

23. Takahashi N, Iwasa S, Sasaki Y, et al. Serum levels of soluble programmed cell death ligand 1 as a prognostic factor on the first-line treatment of metastatic or recurrent gastric cancer. J Cancer Res Clin Oncol 2016; 142: 1727-38.

24. Rossille D, Gressier M, Damotte D, et al. High level of soluble programmed cell death ligand 1 in blood impacts overall survival in aggressive diffuse large B-Cell lymphoma: results from a French multicenter clinical trial. Leukemia 2014; 28 (12): 2367-75.

25. Ruf M, Moch H, Schraml P. PD-L1 expression is regulated by hypoxia inducible factor in clear cell renal cell carcinoma. Int J Cancer 2016; 139: 396-403.

26. Zheng Z, Bu Z, Liu X, et al. Level of circulating PD-L1 expression in patients with advanced gastric cancer and its clinical implications. Chin J Cancer Res 2014; 26:104-11.

27. Zhang J, Gao J, Li Y, et al. Circulating PD-L1 in NSCLC patients and the correlation between the level of PD-L1 expression and the clinical characteristics. Thorac Cancer 2015; 6: 534-38.

28. Wei $W, X u B$, Wang $Y$, et al. Prognostic significance of circulating soluble programmed death ligand-1 in patients with solid tumours. A meta-analysis. Medicine 2018; 97(3): e9617.

29. Zhao J, Zhang P, Wang J, et al. Plasma levels of soluble programmed death ligand-1 may be associated with overall survival in nonsmall cell lung cancer patients receiving thoracic radiotherapy. Medicine 2017; 96(7): e6102.

30. Del ReM, Marconcini R, Pasquini G, et al. PD-L1 mRNA expression in plasma-derived exosomes is associated with response to anti-PD-1 antibodies in melanoma and NSCLC. British Journal of Cancer 2018; 118: 820-4.

31. Chen G, Huang AC, Zhang W, et al. Exosomal PD-L1 contributes to immunosuppression and is associated with anti-PD-1 response. Nature 2018 Aug; 560 (7718): 382-6.

32. Dai SW, Wang XM, Liu LY, et al. Discovery and identification of Serum Amyloid A protein elevated in lung cancer serum. Sci China Ser C-Life Sci 2007; 50 (3): 305-11.

33. Planque $C$, Kulasingam V, Smith $C R$, et al. Identification of five candidate lung cancer biomarkers by proteomics analysis of conditioned media of four lung cancer cell lines. Mol Cell Proteomics 2009; 8(12): 2746-58.

34. Cremona M, Calabro E, Randi G, et al. Elevated levels of the acute-phase serum amyloid are associated with heightened lung cancer risk. Cancer 2010; 116(5): 1326-35.

35. Chen DS, Mellman I. Elements of cancer immunity and the cancer-immune set point. Nature 2017; 541 (7637): 321-30.

36. Hegde PS, Karanikas V, Evers S. The where, the when, and the how of immune monitoring for cancer immuno- 
therapies in the era of checkpoint inhibition. Clin Cancer Res 2016; 22: 1865-74.

37. Fehrenbacher L, Spira A, Ballinger M.et al. Atezolizumab versus docetaxel for patients with previously treated nonsmall-cell lung cancer (POPLAR): a multicenter, openlabel, phase 2 randomised controlled trial. Lancet 2016; 387(10030): 1837-46.

38. Richter I, Jirasek T, Dvorak J, et al. The prognostic effects of neoadjuvant chemoradiotherapy on the change of PDL1 expression in patients with locally advanced rectal adenocarcinoma. J Buon 2017; 22: 875-81.
39. McDermott DF, Sosman JA, Sznol M, et al. Atezolizumab, an anti-programmed death-ligand 1 antibody, in metastatic renal cell carcinoma: long-term safety, clinical activity, and immune correlates from a phase la study. J Clin Oncol 2016; 34(8): 833-42.

40. Sung HJ, Ahn JM, Yoon YH, et al. Identification and validation of SAA as a potential lung cancer biomarker and its involvement in metastatic pathogenesis of lung cancer. J Proteome Res 2011; 10(3): 1383-95.

Received: July 25, 2018

Accepted: September 29, 2018 